\title{
The Concept of Autonomy and Its Role in Kantian Ethics
}

\author{
IAIN BRASSINGTON
}

\section{Bioethics and Autonomy}

Among bioethicists, and perhaps ethicists generally, the idea that we are obliged to respect autonomy is something of a shibboleth. Appeals to autonomy are commonly put to work to support legal and moral claims about the importance of consent, but they also feed a wider discourse in which the patient's desires are granted a very high importance and medical paternalism is regarded as almost self-evidently indefensible. Beauchamp and Childress's four principles-which have, for better or worse, shaped a large portion of modern bioethical debate-do not officially grant respect for autonomy any precedence over beneficence, nonmaleficence, or justice. ${ }^{1}$ Nevertheless, there is no shortage of people who accept "principlism" and who have taken the principle of respect for autonomy to be "first among equals." ${ }^{2}$ Others reject principlism but still hold respect for autonomy to be important-perhaps overridingly so.

But what does "autonomy" mean? If we are prepared to say that autonomy is important, or more or less important than something else, it is not crazy to think that we ought to be clear concerning that about which we are speaking. The meaning of the word autonomy is not obvious: the list of competing interpretations at the start of Dworkin's Theory and Practice gives a flavor of its polysemy. ${ }^{3}$ Maybe the meaning of any given word is protean and context dependent, but it would remain possible even then to show that a particular interpretation is incoherent, or that the word is being misappropriated.

I cannot give a comprehensive survey and analysis of the meanings of autonomy here. But because the modern interest in respect for autonomy can be traced to Kant, it is worth examining what he holds the nature and characteristics of autonomy to be. The warrant for such an examination is strengthened by the fact that at least some bioethicists think not only that autonomy is important and that respect for it makes certain demands, but also that it is best understood in ostensibly Kantian terms. Yet Richard Dean has argued that autonomy in the mouth of a bioethicist has little, if anything, to do with Kant's use of the term, ${ }^{4}$ and although my concerns differ from Dean's, I agree that the bioethicist's autonomy is different from Kant's, and I shall suggest that one of the prevailing uses of Kantian autonomy within bioethicsthat we ought to respect it as a way of respecting persons-is mistaken. A Kantian bioethic is not what many bioethicists think it is. 


\title{
Freedom and Humanity
}

To elucidate what Kant means by autonomy, and why it merits respect, it is worth sketching out Kant's moral theory. I shall take as my starting point the supposition that, for an action to have any moral weight, it must be free. (The justification for this supposition will appear shortly.) For Kant, free actions are those that are based in an agent's will. This line, suitably filled out, promises to make satisfactory sense of the intuitive distinction between free and impulsive actions. Nevertheless, it raises another question: what is the will? For Kant, the will is practical reason. ${ }^{5}$ So there is clearly a close relationship between reason, freedom, and morality.

Importantly, a free action is not undetermined. An agent acting randomly would not be free, because randomness implies a lack of self-control. Nor is freedom a matter of not being under control in any other way, for largely the same reasons. Instead, free actions-the things that we will-must adhere to a certain set of controls. And because freedom is, the Kantian story goes, based in reason, and because reason is governed by a priori and universal laws, it follows that what controls practical reason, therefore freedom, must follow a pattern set by these laws. Thus Kant claims that "[t]he will is thought of as a faculty of determining itself to action in accordance with the representation of certain laws, and such a faculty can be found only in rational beings" ${ }^{\prime 6}$ and that

\begin{abstract}
[o]nly a rational being has the power to act according to his conception of laws, i.e., according to principles, and thereby he has a will. Since the derivation of actions from laws requires reason, the will is nothing but practical reason [and] the will is a faculty of choosing only that which reason, independently of inclination, recognises as being practically necessary, i.e., as good.
\end{abstract}

The laws of reason, in their practical, conduct-determining manifestation, are what Kant calls moral laws. "Permissible," on this account, is simply a shorthand way of saying "in conformity with the laws that properly determine the will"; "wrong" simply means "in violation of those laws," and "duty" is simply what those laws require-hence we have a duty to do something just when not to do it would violate the moral law. This feeds into the first formulation of the categorical imperative: because it is rational, and reason is taken to be universal, the moral law must be universal and the maxims that it supports universalizable. It is also from this position that we can understand Kant's claim about it being only those actions that derive from duty that are of true moral worth ${ }^{8}$ : those deeds that simply accord with duty cannot be said to draw from the will, and so are a fortiori outside of the moral law's writ. Finally, we can also see how we could provide the justification for the supposition with which I began this section; nonfree actions, not being based in the will, are categorically different from actions of moral worth and so not amenable to moral praise or blame.

Our practical rationality gives us the capacity to originate our actions from within ourselves. Although constrained by the (moral) rules of reason, our willed actions are free in the sense that we dictate the rules that our behavior follows for ourselves. This is as much as to say that our wills are autonomous. Indeed, in the Grounding, Kant defines autonomy of the will-and he is concerned about the autonomy of the will more than about the autonomy of persons-as "the 
property that the will has of being a law unto itself (independently of any property of the objects of volition). ${ }^{\prime 9}$ Moreover, we are free actors only when, and to the extent that, our actions are determined by the operation of reason (thus "[t]he power to judge autonomously . . . is called reason" ${ }^{\prime 10}$ ). Autonomy is, on this account, not the freedom from law or $a$ law, but the freedom to be bound-bound, that is, by a law that is wholly self-given.

And yet, because reason is universal, it follows that the law that the unobstructed will would give itself is universal, and so formally the same for all agents at all times. This means that our moral freedom does not mandate idiosyncrasy or uniqueness. Rather, as a matter of necessity, its expression will be the same for all rational beings. If this reading is correct, autonomy is not (as Onora O'Neill suggests) "expressed in action whose principle could be adopted by all others." ${ }^{11}$ What is in fact the case is that the principle would inevitably be expressed by all others.

At first blush, this seems paradoxical. However, it need not be so. Consider an analogy from mathematics. I am assured that there are hundreds of different proofs of Pythagoras's theorem, and different mathematicians may come up with all kinds of ways of demonstrating it. Still, they will not be able to avoid the fact that it is sound. By working out the proof for themselves, they are not thereby setting the rule ex nihilo, but being constrained to follow certain rules of mathematical reasoning and to come to a certain conclusion is not a curb on intellectual freedom. In the moral context, Kant would say that, there being only one rationality, there is only one form that the moral law could take; he claims that "the moralist rightly says that there is only one virtue and one doctrine of virtue," just as there is only one chemistry. ${ }^{12}$ Autonomy is the ability to dictate that moral law for and to ourselves-but nothing more than to dictate it. That an autonomous agent gives himself the law is one thing; what the law that he gives himself states is quite another.

We can now see why Kant thinks that autonomy is worthy of respect: autonomy being nothing more than the capacity to dictate the moral law, it demands respect as a cipher of reverence for that moral law. (And, on this note, remember that, for Kant, "the starry heavens above me and the moral law within me" are the only two things that "fill the mind with ever new and increasing admiration and reverence."13) "Naked" autonomy is, effectively, the same as practical morality, and because naked autonomy would not seem to be compatible with being put under another person's direction, it follows that coercion is de facto a violation of the moral law as it manifests itself in agents, and so something that we have a duty to avoid.

At the same time, persons are valuable not because of their membership within a particular species, but rather because of the very thing that makes them persons in the first place: the operation of the moral law within them. Respecting autonomy is not a matter of expressing respect for persons, and personhood is not something morally weighty in its own right. Rather, as far as Kant is concerned, personhood demands respect simply because it is the mantle of autonomy. And this is an important difference between what I think Kant thought he meant, and what a lot of modern (bio)ethicists think, or think that Kant meant. For them, respecting autonomy is a way of respecting persons; for Kant, things are the other way around. In that vein, when Richard Norman equates Kantianism with "respect for persons" in The Moral Philosophers, ${ }^{14}$ I think he strikes the wrong note; respect for persons just isn't what Kant is about. 
Granted, the second formulation of the categorical imperative tells us that we should treat humanity in ourselves and in others always as an end in itself, ${ }^{15}$ and this seems to imply that Kant gives personhood priority. However, I think that this would be a misinterpretation. For Kant, "[h]umanity itself is $a$ dignity" (Die Menschheit selbst ist ein Würde); ${ }^{16}$ it is not identical with dignity, nor does it endow dignity; the dignity that we have cannot be reduced to humanity, which is merely an aspect of the operation of the moral law within us. It is rational nature that exists as an end in itself, and the second formulation of the categorical imperative is, he indicates, simply its practical manifestation. ${ }^{17}$ Correspondingly, dignity resides in the act of legislation (Gesetzgebung) that determines all worth-that is to say, in the generation of value-determining laws, rather than those laws themselves, or the creature in which that generation takes place. This legislation is a function of autonomy, not of humanity, and it is autonomy that is "the ground of the dignity of human nature and of every rational nature." 18 This indicates that human nature - and so personhood-has to cede priority to the autonomy that is at work in it and makes it personal to begin with. Although "[e]very human being has a legitimate claim to respect from his fellow human beings," ${ }^{19}$ it is the operation of the moral law within them that carries the moral weight: at the core, respect is due to persons because of autonomy.

Naturally, it might be that Kant had made a mistake, and that personhood qua personhood is important after all. But we would still need to construct an argument to back up such a claim. More importantly for my concerns here, when Kant is wheeled in as providing a foundation for claims about respect for persons, he ought to be treated with some care: a Kantian ethic arguably has very different concerns.

\section{Overriding Choices without Undermining Autonomy}

The manner in which it is the operation of the moral law that exercises Kant's imagination, rather than any particular direct concern for the agent in whom it is working or any particular details concerning that agent, generates consequences in respect of the propriety of imposing actions on people.

If the emphasis is on autonomy, rather than on the person, and given Kant's understanding of what he means by "autonomy," we can say that the things that a person may do on a whim or desire outside of the legislation of the moral law are of "no true moral worth." ${ }^{20}$ A naïve understanding of this may lead us to conclude that a person's preferences can be ignored unless they are rationally grounded (which would perhaps make them unrecognizable as preferences to begin with). This would be a mistake, for two reasons. First, a preference's being of no true moral worth doesn't itself provide a reason to override it-and, taking a hint from the Doctrine of Virtue, we may still have an indirect duty not to do $\mathrm{so}^{21}$ the most it means is that one can separate respect for agents' autonomy from respect for their preferences. Second, and more important, autonomy is possible in respect of mere preferences, inasmuch as it is the process by which a rational will has set for itself the laws according to which it will achieve a given end. If it is autonomy that we are supposed to respect, then this is all we need. Even though picking one kind of ice cream rather than another may not be of moral import, there is still an indirect moral reason to respect the choice, and a direct moral reason to respect the autonomy that puts that choice into action. 


\section{Iain Brassington}

So we will usually have to let even whimsical decisions stand. Nevertheless, "usually" is not the same as "always." There may be certain ends that cannot be achieved by acting in a manner determined by the moral law, and therefore cannot be achieved through the exercise of autonomy, which is why we don't have to respect (putatively) autonomously pursued evil. We may have a duty to tell the truth to the murderer at the door, and our doing so may allow him to commit his murder ${ }^{22}$-but it does not follow from that that we have to accept that he was entitled to do so based on an appeal to his autonomy.

For another thing, there may be times when we are not only entitled to constrain a person from acting according to his strongest presently occurring whim or desire, but also have a positive moral reason, based in respect for autonomy, to do exactly that.

The background to this claim is Kant's suspicion of what he calls in the second Critique the "heteronomy of choice": ${ }^{23}$ to allow a person to act in a manner determined solely by the nonfree contingencies of their neurochemistry is not the same as respecting their autonomy. There is evidence pointing to a similar sort of claim elsewhere in his work. For example, he denies in the Grounding that the ends that a person might give himself necessarily "provide any universal principles"; they may only generate hypothetical imperatives, ${ }^{24}$ which would presumably not be protected by the categorical norm about respecting autonomy. The claim also hints that there might be ends that ought to be rejected outright.

Perhaps more importantly when we're considering constraint, he claims that

[t]he human being is a being with needs, insofar as he belongs to the sensible world, and to this extent his reason certainly has a commission from the side of his sensibility which it cannot refuse, to attend to its interest and to form practical maxims with a view to happiness in this life and, where possible, in a future life as well. ${ }^{25}$

Presumably, if an agent's sensible side is commanding him to do things that are not conducive to the satisfaction of his needs, whatever they turn out to be, then it would not be improper for his moral side to overrule those commands. Reason may be likened to a good butler, commissioned to attend to what his employer ought to instruct, or would have instructed had he been thinking straight, or thinks he actually did instruct. More prosaically, this sort of stewardship might be seen in the ex-smoker whose self-discipline is informed by an account of what the body really does need, rather than by what the nicotine-deprived brain believes it needs.

However, it is not clear why, if an agent can have a set of ends that are permissibly, and maybe properly, overruled by his own moral judgments, it may not be permissible for someone else's judgment to do the job when "autochthonic" moral judgments are lacking. Imagine, for example, a person whose actions are attributable to a long-standing mental illness, or an addiction, or something of the like. We have, in this case, a reason to suppose that his action is not autonomous. But we also have a reason to believe that, with the right treatment, the illness could be cured or controlled, or the addiction broken. In this sort of case, it might not only be permissible to impose treatment-where there is diminished autonomy, there is obviously less autonomy to violate-but also, at times, obligatory, and the obligation would derive exactly from a respect for the 
autonomy that we hope to cultivate or restore. In effect, we might be able to "rescue" someone from the heteronomy of his choices. ${ }^{26}$

Undeniably, making a decision for others is also heteronomous-the formal sameness of autonomy between agents for which I argued previously does not imply that those agents are interchangeable; for example, the good kings of neighboring countries may pass identical laws, but that is different from one ruling in the other's stead-but it is no more so than those others' nonrational decisions themselves. Something similar might apply in the case of a person whose first- and second-order desires were in intractable conflict; we might be able to intercede to clear the thicket. We could impose their own capacity for autonomy on them. On this basis, we would seem to have the potential for a defense of substituted judgment far more often than many accounts of bioethics would concede: no nonrational course of action would be immune from interference.

I have found, I admit, no direct textual evidence for there being a positive injunction to substitute judgment in this way, but Kant does claim that the "principle of innate freedom" involves "a human being's quality of being his own master," 27 and if someone's action is determined by neurochemistry rather than rational autonomy, there would be grounds to deny that he is his own master, and so to propose that he is not in a position to express innate freedom anyway. Naturally, we would have to be certain of our motivation and the genuine failure of freedom in the object of our attention, and we would have to be sure that we are not simply imposing our own concepts of happiness on others who happen not to share them, ${ }^{28}$ but inasmuch as our paternalism was based in, rather than simply according with, an impersonal and disinterested respect for autonomy, it may be at worst compatible with the moral law. It is certainly not as indefensible as many modern bioethicists assume it to be. Moreover, and with one eye on the intuitive difference between overriding our own and someone else's "mere" desires, I argue in the next section that the metaphysical gap between self and other, qua moral agent, is vanishingly narrow-but this requires a different argument and cannot be established by anything said so far.

If my reconstruction of Kant so far has any strength to it, it would appear that there is a significant difference between respecting autonomy in Kant's sense and respecting it in the more laissez-faire sense prevalent in a lot of bioethics. Although there is a trend in modern bioethics to treat respect for autonomy as equivalent to a kind of Millian liberal norm about letting people do what they want, this is not what Kant means. A bioethic based on Kantian autonomy as I have presented it would be potentially a lot more interventionist than Kantianism is often taken to allow.

\section{Whose Autonomy?}

The reconstruction of Kant that I have offered so far has two basic aspects. First, autonomy has priority over respect for persons; it is the moral law acting within persons that is the true object of attention. Second, personal idiosyncrasies and particular desires are therefore not of any particular moral importance. If those desires conflict with the operation of the moral law within a person, that is too bad for the desires. All the same, the emphasis so far has been on the nomos part of the word "autonomy," and on the claim that, formally at least, that law is the 
same for all people. We could leave things at that, but, having examined the nomos, it is tempting to wonder what would be revealed by an examination of the auto. What can we say about the agents within whom the moral law is expressed?

It turns out that to talk confidently even about "agents" in the plural might not be as straightforward as we would expect. Although we can clearly differentiate people qua members of the sensible world, we know that it is important for Kant that we are of dual nature-members of both the sensible and intelligible world. As far as Kant is concerned,

a rational being must regard himself qua intelligence as belonging not to the world of sense but to the world of understanding. Therefore he has two standpoints from which he can regard himself and know laws of the use of his powers and hence of all his actions: first, insofar as he belongs to the world of sense subject to laws of nature (heteronomy); secondly, insofar as he belongs to the intelligible world subject to laws which, independent of nature, are not empirical but founded on reason.

As a rational being and hence belonging to the intelligible world, can man never think of the causality of his own will except under the idea of freedom. ... Now the idea of freedom is inseparably connected with the idea concept of autonomy, and this in turn with the universal principle of morality, which ideally is the ground of all actions of rational beings, just as natural law is the ground of all appearances. ${ }^{29}$

Insofar as he is rational (Kant claims), an agent must regard himself as a member of the world of understanding - and this is contrasted with that of appearances. The moral side of an agent does not belong to the world of experience. On one possible understanding, this claim simply helps hold down the idea that a person's particular inclinations have no real moral sway, because they are definitely aspects of his empirical—that is to say, nonmoral-side. They provide data for his understanding of himself, but not any input into his autonomy properly understood. Such an understanding can be pushed further.

When I say that $I$ will this or that, or that such-and-such is a characteristic of $m y$ will, I must be referring to myself or to my will as I experience them. But we have seen just now how Kant thinks that thinking of oneself as a moral agent requires thinking of oneself as belonging to the intelligible world. To the extent that we are capable of free and autonomous action, we are so capable only insofar as we are members of the nonempirical world. This, however, makes talk of my will look difficult, for the grammar of such talk presupposes sensibility. Or, seen from the other side, to the extent that the will is free, we cannot talk about it being any particular person's will at any particular time, because to do so would be to relegate it to the world of experience. It has the appearance of being "my" will, but this is not the same as being able to say that it truly is mine in that possessive sense. Because it is supersensible, terms such as "mine" or "thine" lose their currency.

This throws into question the auto in "autonomy." Although there is no scope for one person substituting his dictation of the moral law for another's when that other is autonomous in Kant's moral view, this turns out plausibly to have at least something to do with the possibility that, on the moral level at least, there really is no difference between these agents in the first place.

Here is how Mark Walker describes the situation: "[R]ational agents qua practically free are non-phenomenal and . . . qua non-phenomenal, a rational 
agent is metaphysically universal in nature." This is entirely compatible with the first formulation of the categorical imperative.

\begin{abstract}
[P]ut crudely, I should act only on maxims that I could will all other rational agents to act on because qua rational agent I am them, so in willing myself to act on a maxim I am committed to willing that they act on it as well. ...

[T]ake "person" to refer to any rational self-conscious agent, and "human being" to refer to a certain form of empirical embodiment of such agency. Then while I am clearly not the same human being as you, I might be identical with you as a person. Hence, as a person I am (possibly) not distinct from you. ${ }^{30}$
\end{abstract}

To the extent that there is moral agency at all, it is not something that can be easily isolated within ostensibly individual moral agents.

If this is correct, it threatens the classic, liberally informed account of autonomy to which many bioethicists appeal. In the conventional account, I ought not to violate your autonomy because it involves, crudely, the intrusion of my nomos into your realm. However, if we are inclined to deny that there is much of a distinction to be had between me and you, the distinction between my realm and yours turns out to be specious. And if this line is tenable, then the thought that you, qua moral agent, are obliged to keep clear of me, qua moral agent, is simply not sustainable, because you and I are indistinguishable.

\title{
Autonomy and Bioethics
}

The account we have suggests two complementary claims, neither of which sits particularly happily with the understanding of autonomy and agency pervasive within bioethics that individual tastes and preferences are morally important. Claim 1 is that autonomy does not amount to idiosyncrasy, because all autonomy, properly understood, will run along the same tracks; claim 2 is that agents' decisions ought to be substitutable not only because they happen to agree, but also because-metaphysically speaking-the agents themselves are indistinguishable.

Allowing that this is a plausible reading, there is an interesting parallel to be drawn between Kant and Rousseau in respect of claim 1, and between Kant and Schopenhauer in respect of claim 2.

In connection with his concept of a rational general will that would be generated by disinterested individuals and govern a free state, Rousseau writes that the citizen who refuses to obey that general will may legitimately be compelled to do so, and because it is only under the government of the general will that a man can be said to be free, this "is no more than to say that it may be necessary to compel a man to be free." ${ }^{\prime 31}$ It is by dint of being forced to be free that "the voice of duty replaces physical impulse ... and the individual is turned from a limited and stupid animal into an intelligent being and a Man."32 This looks to be very close to the reading of Kant that I have just proposed. There are differences between Kant and Rousseau that should not be ignored, but the similarity of the idea, clear in the latter and imputable to the former, that a respect for (moral) freedom can be squared with some form of compulsion is of more than incidental interest. And what Kant has to say about the relationship of 
rational civil laws to autonomous agency is also of more than merely incidental interest:

For enlightenment . . . all that is needed is freedom. And the freedom in question is the most innocuous form of all-freedom to make public use of one's reason in all matters. ... But only a ruler who is himself enlightened ... may say what no republic would dare to say: Argue as much as you like and about whatever you like, but obey! ${ }^{33}$

Kant doesn't see any necessary contradiction between moral freedom and compulsion when that compulsion is morally derived.

Claim 2-that the difference between you and me is purely phenomenal, and so tells us nothing about our metaphysical nature-is present in Schopenhauer, for whom all distinctions of "self" and "not self" are wholly illusory. The moral implication-that all my decisions qua moral agent have to be universal because there is nothing else for them to be-is also something that has an echo in Schopenhauer; the central theme of his essay On the Basis of Morality is, he thinks, captured in the Sanskrit phrase tat tvam asi: this art thou. ${ }^{34}$ Morality, he thinks, is a function of our recognition that the distinction between self and nonself is merely illusory, whereas "the bad man everywhere feels a thick partition between himself and everything outside him." 35

How do these claims sit alongside those of more recent thinkers? I have already claimed that Kant's autonomy and the modern, liberally informed autonomy of many bioethicists are at odds (as is predicted by Dean). Respecting autonomy is not part of respecting persons; the moral law being universal, actions based in autonomy ought also to be universalizable-so the scope of the moral obligation to respect persons' self-regarding acts based on appeals to respect for autonomy is correspondingly narrow. And because our agency as we experience it is, in Kant's eyes, a poor simulacrum at best of the true state of affairs, we cannot claim ownership over autonomous actions; they aren't ours in the first place.

My reconstruction of Kant also differs from attempts to restate a more characteristically Kantian view of autonomy, such as Onora O'Neill's. In respect of claim 2, O'Neill's reconstruction does not confront the downright strangeness of Kant's "transpersonal" view of agency. This will probably be a relief to Kantians. If Kantian normative thought depended on accepting the transpersonal view that he seems to endorse, it would be doomed; a normative system that draws on a picture of agency that is not confined to a particular point of view located in a particular skull would probably not be intelligible to us, and so we would remain unmoved by its commands (including, of course, the command to respect autonomy). Kant perhaps thinks that his insistence that we are of dual nature sidesteps this problem: it is enough that, qua phenomenal beings, we can represent the moral law to ourselves as a system of commands, and enough that, qua free beings, we adhere to it. But, of course, we are less inclined than was Kant to accept dualism, and so, if we want to retain an intelligible version of Kantian moral thought, we have to ditch claim 2.

Fortunately for Kantians, less is lost by this sacrifice than is preserved despite it; for example, the claim about the substitutability of judgment was bolstered by claim 2 but did not depend on it. One does not have to accept a transpersonal 
view of agency to accept the possibility of the same moral law being independently arrived at by discrete agents. Hence claim 1 lives to fight another day.

In respect of claim 1, $\mathrm{O}^{\prime}$ Neill's Kant is less bold than is mine. This is not to say that her reconstruction is weaker-just that her reconstructed Kant is more willing to take people as he finds them and is correspondingly less "interventionist." Although her Kant is still a long way from being reconciled with Millian liberalism, he is slightly less antagonistic to it, and more in tune with modern intuitions. If such consonance is a virtue in a moral theory, then so much the better for O'Neill's Kant, and so much the worse for mine. I do not think that consonance with intuitions is a criterion for the correctness of any reconstructionalthough it does put the icing on the cake. Either way, the normative content of any putatively Kantian moral system-and how one is to interpret an injunction to respect autonomy that is grounded in Kant-will depend on which reconstruction of his thought has the more power. And, either way, a good deal of what passes as "Kantian" should be rebranded as something else.

\section{Notes}

1. Beauchamp T, Childress J. Principles of Biomedical Ethics. 6th ed. New York: Oxford University Press; 2009:99.

2. Gillon R. Ethics needs principles. Journal of Medical Ethics 2003;29(10):307-12, passim.

3. Dworkin G. The Theory and Practice of Autonomy. Cambridge: Cambridge University Press; 1997:3-6.

4. Dean R. The Value of Humanity in Kant's Moral Theory. Oxford: Oxford University Press; 2006:197-225.

5. Kant I. Grounding for the Metaphysics of Morals. Indianapolis: Hackett;1993:4:412. Where possible, I shall give pagination as it appears in the Prussian Academy edition of Kant's work.

6. See note 5, Kant 1993, at 4:427; emphasis mine.

7. Ibid., at 4:412; emphasis mine.

8. Ibid., at 4:390.

9. Ibid., at 4:440; emphasis mine.

10. Kant I. The conflict of the faculties. In: Kant I. Religion and Rational Theology. Cambridge: Cambridge University Press; 1996, at 7:27.

11. O'Neill O. Autonomy and Trust in Bioethics. Cambridge: Cambridge University Press; 2005, at 85; emphasis mine.

12. Kant I. The Metaphysics of Morals. Cambridge: Cambridge University Press; 1996, at 6:207.

13. Kant I. Critique of Practical Reason. Cambridge: Cambridge University Press; 1997, at 5:161.

14. Norman R. The Moral Philosophers. New York: Oxford University Press; 1998, at $\S 6$.

15. See note 5, Kant 1993, passim.

16. See note 12, Kant 1996, at 6:462; emphasis mine.

17. See note 5, Kant 1993, at 4:429.

18. Ibid., 4:436.

19. See note 12, Kant 1996, at 6:462.

20. See note 5, Kant 1993, at 4:390, 397-9.

21. See note 12, Kant 1996, at 6:443.

22. Kant I. On a supposed right to lie because of philanthropic concerns. In: Kant I. Grounding for the Metaphysics of Morals. Indianapolis: Hackett; 1993, passim.

23. See note 13, Kant 1997, at 5:33.

24. See note 5, Kant 1993, at 4:427-8.

25. See note 13, Kant 1997, at 5:61, emphasis added.

26. Although cf. Law I. Autonomy, sanity and moral theory. Res Publica 2003;9(1):39-56, passim, although esp. 51, para 2.

27. See note 12, Kant 1996, at 6:237. 


\section{Iain Brassington}

28. See note 12 , Kant 1996 , at 6:454.

29. See note 5, Kant 1993, at 4:452-3.

30. Walker M. How Kant should have justified his categorical imperative. Unpublished, 2007.

31. Rousseau JJ. The Social Contract. In: Barker E, ed. Social Contract. London: Oxford University Press; 1960:167-307, at 184 .

32. Ibid., at 185 .

33. Kant I. An answer to the question: What is enlightenment? In: Reiss H, ed. Kant: Political Writings. Cambridge: Cambridge University Press; 1991:54-60, at 55, 59.

34. Schopenhauer A. On the Basis of Morality. Indianapolis: Hackett; 1995, at $\S \S$ III and IV.

35. See note 34, Schopenhauer 1995, at 211. 